\title{
Streptomonospora amylolytica sp. nov. and Streptomonospora flavalba sp. nov., two novel halophilic actinomycetes isolated from a salt lake
}

Correspondence

Wen-Jun Li

wjli@ynu.edu.cn or

liact@hotmail.com

\author{
Man Cai, ${ }^{1}$ Shu-Kun Tang, ${ }^{1}$ Yi-Guang Chen, ${ }^{1,2}$ Yan Li, ${ }^{1}$ Yu-Oin Zhang ${ }^{1,3}$ \\ and Wen-Jun Li ${ }^{1}$
}
${ }^{1}$ The Key Laboratory for Microbial Resources of the Ministry of Education, Laboratory for Conservation and Utilization of Bio-Resources, Yunnan Institute of Microbiology, Yunnan University, Kunming, Yunnan 650091, PR China
${ }^{2}$ College of Bio-resources and Environmental Science, Jishou University, Jishou, Hunan 416000, PR China
${ }^{3}$ Institute of Medicinal Biotechnology, Chinese Academy of Medical Sciences and Peking Union Medical College, Beijing 100050, PR China

The genus Streptomonospora, belonging to the family Nocardiopsaceae (Stackebrandt et al., 1997), was first described by Cui et al. (2001) and emended by Li et al. (2003). Currently, the genus contains three recognized species: Streptomonospora salina (Cui et al., 2001), Streptomonospora alba (Li et al., 2003) and Streptomonospora halophila (Cai et al., 2008b). In order to obtain more extremophilic actinomycetal resources, abundant actinomycetes have been isolated with many

The GenBank/EMBL/DDBJ accession numbers for the 16S rRNA gene sequences of strains YIM $91353^{\top}$ and YIM $91394^{\top}$ are EU442551 and EU442553, respectively.

A figure showing minimum-evolution and maximum-parsimony $16 \mathrm{~S}$ rRNA gene sequence phylogenies and a table showing the fatty acid compositions of strains YIM $91353^{\top}$ and $\mathrm{YIM} 91394^{\top}$ and other members of the genus Streptomonospora are available as supplementary material with the online version of this paper. different media. For the rapid identification of Streptomonospora species, a genus-specific PCR amplification method has been introduced, according to the method described by Zhi et al. (2006), and rapid screening of potential novel taxa of the genus Streptomonospora is possible with PCR-single-strand conformation polymorphism analysis (Cai et al., 2008a). As a result, two Streptomonospora-like strains, YIM $91353^{\mathrm{T}}$ and YIM $91394^{\mathrm{T}}$, were isolated from a salt lake in Xinjiang Province, north-west China.

Strains YIM $91353^{\mathrm{T}}$ and YIM $91394^{\mathrm{T}}$ were isolated from a saline soil sample by plating 1:10 serial dilutions of the sample on starch-casein agar medium ( $\mathrm{pH} 7.0)$ supplemented with $10 \%(\mathrm{w} / \mathrm{v}) \mathrm{NaCl}$ at $37{ }^{\circ} \mathrm{C}$ for 3 weeks. The composition of the starch-casein agar medium was $\left(1^{-1}\right)$ : $10 \mathrm{~g}$ starch, $0.3 \mathrm{~g}$ casein, $2 \mathrm{~g} \mathrm{KNO}_{3}, 0.05 \mathrm{~g} \mathrm{MgSO}_{4} .7 \mathrm{H}_{2} \mathrm{O}$, $2 \mathrm{~g} \mathrm{~K}_{2} \mathrm{HPO}_{4}, 0.02 \mathrm{~g} \mathrm{CaCO}_{3}, 0.01 \mathrm{~g} \mathrm{FeSO}_{4}$ and $15 \mathrm{~g}$ agar. 
After primary isolation and purification, the isolates were preserved both on slants of International Streptomyces Project medium 4 agar (ISP 4; Shirling \& Gottlieb, 1966) supplemented with $10 \%(\mathrm{w} / \mathrm{v}) \mathrm{NaCl}$ at $4{ }^{\circ} \mathrm{C}$ and in $20 \%$ $(\mathrm{v} / \mathrm{v})$ glycerol at $-80{ }^{\circ} \mathrm{C}$. Three reference Streptomonospora strains, S. salina YIM $90002^{\mathrm{T}}$, S. alba YIM $90003^{\mathrm{T}}$ and $S$. halophila YIM $91355^{\mathrm{T}}$, were obtained from Yunnan Institute of Microbiology.

Unless otherwise indicated, all tests were carried out with $10 \% \mathrm{NaCl}(\mathrm{w} / \mathrm{v})$ at $\mathrm{pH} 7.0$ and incubated at $37^{\circ} \mathrm{C}$. Morphological characteristics were observed by using light microscopy (BH2; Olympus) and scanning electron microscopy (JSM-5600LV; JEOL) after growth for 2 and 4 weeks on ISP 4 supplemented with $10 \%(w / v) ~ \mathrm{NaCl}$. Anaerobic growth was detected as described previously (Chen et al., 2007). Cultural characteristics were examined using standard growth media according to Shirling \& Gottlieb (1966). The colours of substrate and aerial mycelia and any soluble pigments produced were determined by comparison with chips from the ISCC-NBS colour charts (Kelly, 1964). The media and procedures used to determine physiological and biochemical features and carbon-source utilization patterns were those described by Shirling \& Gottlieb (1966) and Williams et al. (1989). Strains YIM $91353^{\mathrm{T}}$ and YIM $91394^{\mathrm{T}}$ had the typical macroscopic and microscopic appearance of most species of the genus Streptomonospora (Cui et al., 2001; Li et al., 2003; Cai et al., $2008 \mathrm{~b})$. The detailed results of the phenotypic tests are given in the species description and in Tables 1 and 2.

Genomic DNA was prepared from cells lysed with microwaves. PCR amplification and sequencing of the $16 \mathrm{~S}$ rRNA gene were carried out as described previously ( $\mathrm{Li}$ et al., 2007), and the $\mathrm{G}+\mathrm{C}$ content was determined using the HPLC method (Mesbah et al., 1989). The resulting $16 \mathrm{~S}$ rRNA gene sequences were compared with sequences obtained from public databases (GenBank/EMBL/DDBJ) to find the most closely related strains. Phylogenetic analyses were performed using the software package MEGA version 4.1 (Tamura et al., 2007) after multiple alignment of sequence data by CLUSTAL x (Thompson et al., 1997). Distances were calculated using distance options according to Kimura's two-parameter model (Kimura, 1980) and clustering was performed with the neighbour-joining (Saitou \& Nei, 1987), maximum-parsimony (Kluge \& Farris, 1969) and minimum-evolution (Felsenstein, 1997) algorithms by means of methods contained within the software package MEGA version 4.1 (Tamura et al., 2007). Bootstrap analysis was used to evaluate the tree topology by means of 1000 resamplings (Felsenstein, 1985). DNA-DNA hybridizations were carried out using photobiotin-labelled DNA probes and microdilution wells as described by Ezaki et al. (1989). A microplate spectrofluorimeter (Gemini XPS; Molecular Devices) was employed for fluorescence measurements.

The almost-complete 16S rRNA gene sequences of strains YIM $91353^{\mathrm{T}}(1532 \mathrm{bp})$ and YIM $91394^{\mathrm{T}}(1560 \mathrm{bp})$ were
Table 1. Phenotypic characteristics that differentiate strains YIM $91353^{\top}$ and YIM $91394^{\top}$ from each other and recognized Streptomonospora species

Strains: 1, S. amylolytica sp. nov. YIM $91353^{\mathrm{T}} ; 2$, S. flavalba sp. nov. YIM $91394^{\mathrm{T}}$; 3, S. salina YIM $90002^{\mathrm{T}} ;$ 4, S. alba YIM $90003^{\mathrm{T}} ; 5$, S. halophila YIM $91355^{\mathrm{T}}$. Data were taken from this study. All strains were positive for catalase production. All strains were negative for gelatin liquefaction, hydrolysis of urea and utilization of acetate, adonitol, citrate, dextrin, dulcitol, erythrose, fructose, galactose, gluconate, lactose, malonate, mannitol, mannose, melibiose, melezitose, raffinose, ribose, salicin, sorbose, sucrose, tartrate, turanose, xylitol, adenine, asparagine, glutamic acid, methionine and valine. +, Positive; -, negative.

\begin{tabular}{|llllll|}
\hline Characteristic & $\mathbf{1}$ & $\mathbf{2}$ & $\mathbf{3}$ & $\mathbf{4}$ & $\mathbf{5}$ \\
\hline Hydrolysis of: & & & & & \\
Cellulose & - & - & - & - & + \\
Starch & + & + & + & - & - \\
Milk coagulation & + & + & - & - & - \\
Milk peptonization & + & + & - & - & + \\
Nitrate reduction & - & - & - & + & - \\
Production of: & & & & & \\
H2S & + & - & - & - & - \\
Melanin & - & + & + & - & - \\
Oxidase & - & - & + & - & - \\
Uitilization of: & & & & & \\
Arabinose & + & + & + & - & - \\
Cellobiose & + & - & - & - & - \\
Glucose & + & + & + & + & - \\
Inositol & - & - & - & - & + \\
Maltose & - & + & + & - & + \\
Rhamnose & + & + & - & - & + \\
Sorbitol & + & - & - & - & - \\
Alanine & - & + & - & - & + \\
Arginine & + & + & - & - & - \\
Glycine & - & + & - & - & - \\
Histidine & - & + & + & - & + \\
Hydroxyproline & + & - & - & - & - \\
Lysine & + & - & - & - & - \\
Phenylalanine & - & + & - & - & + \\
Proline & + & + & - & - & + \\
Serine & - & + & - & - & - \\
Threonine & + & + & - & - & + \\
Tryptophan & + & + & - & - & - \\
Tyrosine & - & + & - & - & - \\
\hline & & & & & \\
\hline & & & & &
\end{tabular}

determined. Preliminary comparison of the sequences against the GenBank database indicated that these isolates were closely related to the members of the genus Streptomonospora. In all of the three phylogenetic trees, strains YIM $91353^{\mathrm{T}}$ and YIM $91394^{\mathrm{T}}$ formed a stable clade with the three recognized Streptomonospora species (Fig. 1 and Supplementary Fig. S1, available in IJSEM Online). The levels of 16S rRNA gene sequence similarities for $S$. alba YIM $90003^{\mathrm{T}}$, S. salina YIM $90002^{\mathrm{T}}$ and S. halophila YIM $91355^{\mathrm{T}}$ with strain YIM $91353^{\mathrm{T}}$ were $99.3,98.8$ and $96.7 \%$, respectively, and with strain YIM $91394^{\mathrm{T}}$ were 99.6, 


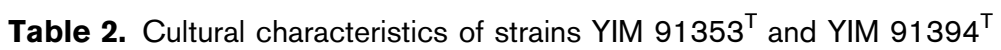

All media were adjusted to pH 7.0 and supplemented with $10 \%(\mathrm{w} / \mathrm{v}) \mathrm{NaCl}$. Diffusible pigments were not produced on any of the media tested except for strain YIM $91394^{\mathrm{T}}$, which produced deep yellow diffusible pigments on potato extract agar. -, No growth.

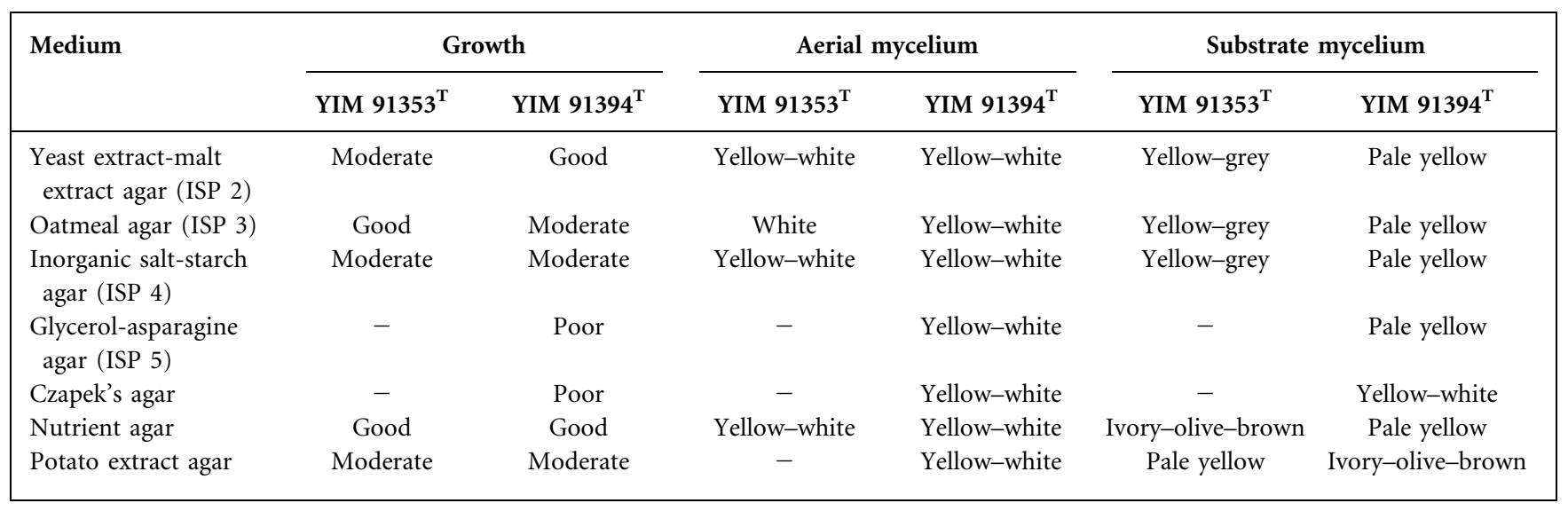

98.9 and $96.9 \%$, respectively. The similarity between the two novel isolates was $98.7 \%$.

To establish the precise taxonomic positions of the novel isolates, DNA-DNA hybridizations were performed. The levels of DNA-DNA relatedness for S. salina YIM $90002^{\mathrm{T}}$ and S. alba YIM $90003^{\mathrm{T}}$ with strain YIM $91353^{\mathrm{T}}$ were 47.3 and $45.7 \%$, respectively, and with YIM $91394^{\mathrm{T}}$ were 46.8 and $25.1 \%$, respectively. The DNA-DNA relatedness value for strains YIM $91353^{\mathrm{T}}$ and YIM $91394^{\mathrm{T}}$ was $37.4 \%$. These values were significantly lower than the threshold of $70 \%$ for the delineation of genomic species (Wayne et al., 1987). It is therefore evident, based on the phylogenetic analysis and DNA-DNA hybridization data, that strains YIM $91353^{\mathrm{T}}$ and YIM $91394^{\mathrm{T}}$ represent two novel species of the genus Streptomonospora.

Amino acids and sugars of whole-cell hydrolysates were analysed on the basis of the methods established by Lechevalier \& Lechevalier (1980) and Staneck \& Roberts (1974), respectively. Polar lipids were extracted, examined by using two-dimensional TLC and identified using described procedures (Minnikin et al., 1979). Isoprenoid quinones were analysed by HPLC as described by Groth et al. (1996). Fatty acids were determined for the isolates as well as for the three reference strains, S. salina YIM $90002^{\mathrm{T}}$,
S. alba YIM $90003^{\mathrm{T}}$ and S. halophila YIM $91355^{\mathrm{T}}$, as described by Sasser (1990) using the Microbial Identification System (MIDI) with cells grown in trypticase soy broth (BBL) supplemented with $10 \%$ (w/v) $\mathrm{NaCl}$ $(\mathrm{pH} 7.0)$ in flasks on a rotary shaker $(200$ r.p.m. $)$ at $37{ }^{\circ} \mathrm{C}$ for 3 days. Chemotaxonomic data for the novel isolates were consistent with their assignment to the genus Streptomonospora (Cui et al., 2001; Li et al., 2003; Cai et al., 2008a). The cell-wall diamino acid in the peptidoglycan layer of both strains was meso-diaminopimelic acid and the whole-cell sugars were galactose and glucose with a trace of mannose. The phospholipids of the two isolates consisted of diphosphatidylglycerol, phosphatidylcholine, phosphatidylglycerol, phosphatidylinositol and phosphatidylinositol mannosides. The predominant menaquinones were $\mathrm{MK}-10\left(\mathrm{H}_{8}\right)(35.8 \%), \mathrm{MK}-10\left(\mathrm{H}_{6}\right)(16.4 \%)$ and $\mathrm{MK}-$ $9\left(\mathrm{H}_{8}\right)(15.3 \%)$ for strain YIM $91353^{\mathrm{T}}$, and $\mathrm{MK}-10\left(\mathrm{H}_{8}\right)$ (41.5\%), MK-9 $\left(\mathrm{H}_{8}\right)(27.7 \%)$ and $\mathrm{MK}-10\left(\mathrm{H}_{6}\right)(12.6 \%)$ for strain YIM $91394^{\mathrm{T}}$. The fatty acid profiles of the novel isolates were similar to those of the type strains of species of the genus Streptomonospora (Supplementary Table S1, in IJSEM Online).

The results of the 16S rRNA gene sequence analysis clearly demonstrated that strains YIM $91353^{\mathrm{T}}$ and YIM $91394^{\mathrm{T}}$ belong to the genus Streptomonospora. Both organisms

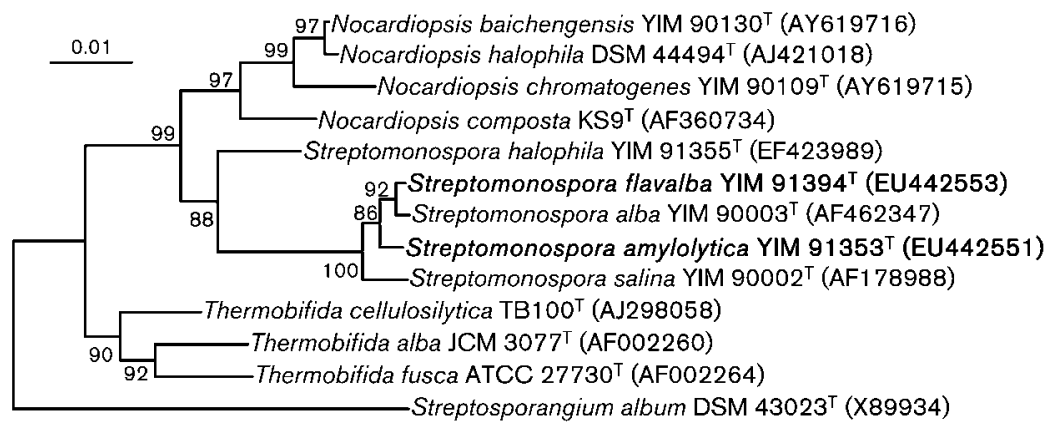

http://ijs.sgmjournals.org
Fig. 1. Phylogenetic tree based on $16 \mathrm{~S}$ rRNA gene sequence analysis, reconstructed from evolutionary distances with the neighbourjoining method, showing the phylogenetic positions of strains YIM $91353^{\top}$ and YIM $91394^{\top}$ and related taxa. Bootstrap values based on 1000 replicates are shown at branch nodes. Streptosporangium album DSM $43023^{\top}$ was used as the outgroup. Bar, 1 substitution per 100 nucleotide positions. 
contained $\mathrm{MK}-10\left(\mathrm{H}_{8}\right)$ and $\mathrm{MK}-10\left(\mathrm{H}_{6}\right)$ as the predominant menaquinones and meso-diaminopimelic acid as the diagnostic amino acid in the peptidoglycan and, together with their similar fatty acid profiles, these properties also supported the inclusion of strains YIM $91353^{\mathrm{T}}$ and YIM $91394^{\mathrm{T}}$ within the genus Streptomonospora. However, the two novel isolates could be distinguished from each other and from recognized Streptomonospora species with a range of phenotypic and chemotaxonomic differences (Tables 1 and 2 and Supplementary Table S1). On the basis of the results of the phylogenetic analysis, the DNA-DNA hybridization data and the phenotypic and chemotaxonomic properties presented above, we propose that strains YIM $91353^{\mathrm{T}}$ and YIM $91394^{\mathrm{T}}$ represent two novel species of the genus Streptomonospora, Streptomonospora amylolytica sp. nov. and Streptomonospora flavalba sp. nov., respectively.

\section{Description of Streptomonospora amylolytica sp. nov.}

Streptomonospora amylolytica (a.my.lo.ly.ti'ca. Gr. n. amylos starch; Gr. adj. lutikos dissolving; N.L. fem. adj. amylolytica producing lysis of starch).

Gram-positive, aerobic, catalase-positive, oxidase-negative. Grows well on oatmeal agar and nutrient agar media supplemented with $10 \%(\mathrm{w} / \mathrm{v}) \mathrm{NaCl}$, but not on Czapek's agar or glycerol/asparagine agar supplemented with $10 \%$ $(\mathrm{w} / \mathrm{v}) \mathrm{NaCl}$. Diffusible pigments are not produced on all media tested. Aerial and substrate mycelia are not fragmented. White to yellow-white aerial mycelia form spore chains at maturity, with non-motile, oval to cylindrical spores $(0.3-0.4 \times 0.4-0.6 \mu \mathrm{m})$. Single, oval spores are borne on sporophores of substrate mycelium. Substrate mycelia are yellow-grey on inorganic salt-starch agar, yeast extract-malt extract agar and oatmeal agar, pale yellow on potato extract agar and ivory-olive-brown on nutrient agar. Growth occurs with 5-20\% (w/v) $\mathrm{NaCl}$ (optimum, $10 \%$ ), at $20-45{ }^{\circ} \mathrm{C}$ (optimum, $37{ }^{\circ} \mathrm{C}$ ) and at pH 5.0-9.0 (optimum, pH 7.0). Utilizes arabinose, cellobiose, glucose, rhamnose and sorbitol as sole carbon and energy sources, and arginine, hydroxyproline, lysine, proline, threonine and tryptophan as sole nitrogen, carbon and energy sources. Positive for hydrolysis of starch, $\mathrm{H}_{2} \mathrm{~S}$ production and milk coagulation and peptonization, but negative for gelatin liquefaction, hydrolysis of cellulose and urea, melanin production and nitrate reduction. The diagnostic amino acid of the cell-wall peptidoglycan is meso-diaminopimelic acid, and galactose is the major diagnostic sugar in whole-cell hydrolysates. The predominant menaquinones are MK- $10\left(\mathrm{H}_{8}\right)$, MK- $10\left(\mathrm{H}_{6}\right)$ and MK$9\left(\mathrm{H}_{8}\right)$. Polar lipids consist of diphosphatidylglycerol, phosphatidylcholine, phosphatidylglycerol, phosphatidylinositol and phosphatidylinositol mannosides. Major fatty acids are anteiso- $\mathrm{C}_{17: 0}$ and $\mathrm{C}_{18: 0}$. Other phenotypic properties are given in Table 1. The DNA G $+\mathrm{C}$ content of the type strain is $71.2 \mathrm{~mol} \%$ (HPLC).
The type strain, YIM $91353^{\mathrm{T}}\left(=\mathrm{DSM} 45171^{\mathrm{T}}=\right.$ CCTCC AA $208048^{\mathrm{T}}$ ), was isolated from saline soil collected from a salt lake in Xinjiang Province, north-west China.

\section{Description of Streptomonospora flavalba sp. nov.}

Streptomonospora flavalba (fla.val'ba. L. adj. flavus yellow; L. adj. albus white; N.L. fem. adj. flavalba yellow-white, referring to the colour of aerial mycelium).

Gram-positive, aerobic, catalase-positive, oxidase-negative. Grows well on yeast extract-malt extract agar and nutrient agar media supplemented with $10 \%(\mathrm{w} / \mathrm{v}) \mathrm{NaCl}$, but grows poorly on Czapek's agar or glycerol/asparagine agar supplemented with $10 \%(\mathrm{w} / \mathrm{v}) \mathrm{NaCl}$. Diffusible pigments are not produced on most media tested, except for potato extract agar ( $\mathrm{pH} 7.0)$ supplemented with $10 \%(\mathrm{w} / \mathrm{v}) \mathrm{NaCl}$, on which deep yellow diffusible pigments are produced. Aerial and substrate mycelia are not fragmented. Yellowwhite aerial mycelia form spore chains at maturity, with non-motile, oval to cylindrical spores $(0.5-0.6 \times 0.7-$ $0.9 \mu \mathrm{m})$. Single, oval spores are borne on sporophores of substrate mycelium. Substrate mycelia are pale yellow on inorganic salt-starch agar, oatmeal agar, yeast extract-malt extract agar, glycerol/asparagine agar and nutrient agar and yellow-white on Czapek's agar and ivory-olive-brown on potato extract agar. Growth occurs with $5-25 \%(\mathrm{w} / \mathrm{v})$ $\mathrm{NaCl}$ (optimum, $10 \%$ ), at $20-45{ }^{\circ} \mathrm{C}$ (optimum, $37{ }^{\circ} \mathrm{C}$ ) and pH 5.0-9.0 (optimum, pH 7.0). Utilizes arabinose, glucose, maltose and rhamnose as sole carbon and energy sources, and alanine, arginine, glycine, histidine, phenylalanine, proline, serine, threonine, tryptophan and tyrosine as sole nitrogen, carbon and energy sources. Positive for hydrolysis of starch, melanin production and milk coagulation and peptonization, but negative for gelatin liquefaction, hydrolysis of cellulose and urea, $\mathrm{H}_{2} \mathrm{~S}$ production and nitrate reduction. The diagnostic amino acid of the cell-wall peptidoglycan is meso-diaminopimelic acid, and galactose is the major diagnostic sugar in whole-cell hydrolysates. The predominant menaquinones are MK$10\left(\mathrm{H}_{8}\right)$, MK-9 $\left(\mathrm{H}_{8}\right)$ and MK-10 $\left(\mathrm{H}_{6}\right)$. Polar lipids consist of diphosphatidylglycerol, phosphatidylcholine, phosphatidylglycerol, phosphatidylinositol and phosphatidylinositol mannosides. Major fatty acids are anteiso- $\mathrm{C}_{17: 0}$ and iso$\mathrm{C}_{16: 0}$. Other phenotypic properties are given in Table 1 . The DNA G + C content of the type strain is $72.5 \mathrm{~mol} \%$ (HPLC).

The type strain, YIM $91394^{\mathrm{T}}\left(=\right.$ DSM $45155^{\mathrm{T}}=$ CCTCC AA $208047^{\mathrm{T}}$ ), was isolated from saline soil collected from a salt lake in Xinjiang Province, north-west China.

\section{Acknowledgements}

This research was supported by the National Basic Research Program of China (project no. 2004CB719601), National Natural Science Foundation of China (project no. 30600001, 30860002, 30870005) and the Key Project of Chinese Ministry of Education (project no. 
206139). W.-J. L. was also supported by the Program for New Century Excellent Talent in University (NCET).

\section{References}

Cai, M., Zhi, X.-Y., Wu, J.-Y., Tang, S.-K. \& Li, W.-J. (2008a). Rapid selection of halophilic Streptomonospora strains by PCR-SSCP. Microbiology (Beijing) 35, 1500-1504.

Cai, M., Zhi, X. Y., Tang, S.-K., Zhang, Y.-Q., Xu, L.-H. \& Li, W.-J. (2008b). Streptomonospora halophila sp. nov., a novel halophilic actinomycete isolated from a hypersaline soil. Int J Syst Evol Microbiol 58, 1556-1560.

Chen, Y.-G., Cui, X.-L., Pukall, R., Li, H.-M., Yang, Y.-L., Xu, L.-H., Wen, M.-L., Peng, Q. \& Jiang, C.-L. (2007). Salinicoccus kunmingensis sp. nov., a moderately halophilic bacterium isolated from a salt mine in Yunnan, south-west China. Int J Syst Evol Microbiol 57, 2327-2332.

Cui, X.-L., Mao, P.-H., Zeng, M., Li, W.-J., Zhang, L.-P., Xu, L.-H. \& Jiang, C.-L. (2001). Streptomonospora salina gen. nov., sp. nov., a new member of the family Nocardiopsaceae. Int J Syst Evol Microbiol 51, 357-363.

Ezaki, T., Hashimoto, Y. \& Yabuuchi, E. (1989). Fluorometric deoxyribonucleic acid-deoxyribonucleic acid hybridization in microdilution wells as an alternative to membrane filter hybridization in which radioisotopes are used to determine genetic relatedness among bacterial strains. Int J Syst Bacteriol 39, 224-229.

Felsenstein, J. (1985). Confidence limits on phylogenies: an approach using the bootstrap. Evolution 39, 783-791.

Felsenstein, J. (1997). An alternative least-squares approach to inferring phylogenies from pairwise distances. Syst Biol 46, 101-111.

Groth, I., Schumann, P., Weiss, N., Martin, K. \& Rainey, F. A. (1996). Agrococcus jenensis gen. nov., sp. nov., a new genus of actinomycetes with diaminobutyric acid in the cell wall. Int J Syst Bacteriol 46, 234-239.

Kelly, K. L. (1964). Inter-Society Color Council - National Bureau of Standards Color Name Charts Illustrated with Centroid Colors. Washington, DC: US Government Printing Office.

Kimura, M. (1980). A simple method for estimating evolutionary rates of base substitutions through comparative studies of nucleotide sequences. J Mol Evol 16, 111-120.

Kluge, A. G. \& Farris, J. S. (1969). Quantitative phyletics and the evolution of anurans. Syst Zool 18, 1-32.

Lechevalier, M. P. \& Lechevalier, H. A. (1980). The chemotaxonomy of actinomycetes. In Actinomycete Taxonomy, pp. 227-291. Edited by X. Dietz \& Y. Thayer. Arlington, VA: Society for Industrial Microbiology.

Li, W.-J., Xu, P., Zhang, L.-P., Tang, S.-K., Cui, X.-L., Mao, P.-H., Xu, L.-H., Schumann, P., Stackebrandt, E. \& Jiang, C.-L. (2003).
Streptomonospora alba sp. nov., a novel halophilic actinomycete, and emended description of the genus Streptomonospora Cui et al. 2001. Int J Syst Evol Microbiol 53, 1421-1425.

Li, W.-J., Xu, P., Schumann, P., Zhang, Y.-Q., Pukall, R., Xu, L.-H., Stackebrandt, E. \& Jiang, C.-L. (2007). Georgenia ruanii sp. nov., a novel actinobacterium isolated from forest soil in Yunnan (China) and emended description of the genus Georgenia. Int J Syst Evol Microbiol 57, 1424-1428.

Mesbah, M., Premachandran, U. \& Whitman, W. B. (1989). Precise measurement of the $\mathrm{G}+\mathrm{C}$ content of deoxyribonucleic acid by highperformance liquid chromatography. Int J Syst Bacteriol 39, 159-167.

Minnikin, D. E., Collins, M. D. \& Goodfellow, M. (1979). Fatty acid and polar lipid composition in the classification of Cellulomonas, Oerskovia and related taxa. J Appl Bacteriol 47, 87-95.

Saitou, N. \& Nei, M. (1987). The neighbor-joining method: a new method for reconstructing phylogenetic trees. Mol Biol Evol 4, 406-425.

Sasser, M. (1990). Identification of bacteria by gas chromatography of cellular fatty acids. USFCC Newsl 20, 16.

Shirling, E. B. \& Gottlieb, D. (1966). Methods for characterization of Streptomyces species. Int J Syst Bacteriol 16, 313-340.

Stackebrandt, E., Rainey, F. A. \& Ward-Rainey, N. L. (1997). Proposal for a new hierarchic classification system, Actinobacteria classis nov. Int J Syst Bacteriol 47, 479-491.

Staneck, J. L. \& Roberts, G. D. (1974). Simplified approach to identification of aerobic actinomycetes by thin-layer chromatography. Appl Microbiol 28, 226-231.

Tamura, K., Dudley, J., Nei, M. \& Kumar, S. (2007). MEGA4: Molecular Evolutionary Genetic Analysis (MEGA) software version 4.0. Mol Biol Evol 24, 1596-1599.

Thompson, J. D., Gibson, T. J., Plewniak, F., Jeanmougin, F. \& Higgins, D. G. (1997). The CLUSTAL_X windows interface: flexible strategies for multiple sequence alignment aided by quality analysis tools. Nucleic Acids Res 25, 4876-4882.

Wayne, L. G., Brenner, D. J., Colwell, R. R., Grimont, P. A. D., Kandler, O., Krichevsky, M. I., Moore, L. H., Moore, W. E. C., Murray, R. G. E. \& other authors (1987). International Committee on Systematic Bacteriology. Report of the ad hoc committee on reconciliation of approaches to bacterial systematics. Int J Syst Bacteriol 37, 463-464.

Williams, S. T., Goodfellow, M. \& Alderson, G. (1989). Genus Streptomyces Waksman and Henrici 1943, 339 ${ }^{\mathrm{AL}}$. In Bergey's Manual of Systematic Bacteriology, vol. 4, pp. 2452-2492. Edited by S. T. Williams, M. E. Sharpe \& J. G. Holt. Baltimore: Williams \& Wilkins.

Zhi, X.-Y., Tang, S.-K., Li, W.-J., Xu, L.-H. \& Jiang, C.-L. (2006). New genus-specific primers for the PCR identification of novel isolates of the genus Streptomonospora. FEMS Microbiol Lett 263, 48-53. 